\title{
HERMES, JANO Y UN ERROR DE BORGES EN $L A$ MUERTE Y LA BRUUULA
}

\author{
Manuel Sanz Morales \\ Universidad Autónoma de Madrid
}

Fernando Pessoa escribió que una de las escasas diversiones intelectuales que aún le queda a lo que aún queda de intelectual en la humanidad es la lectura de narraciones policiacas. Este pesimismo cultural se entiende mucho mejor después de haber leido los bocetos y relatos policiacos del propio Pessoa, con los que poco contribuyó a aliviar de dicha escasez de divertimiento a la humanidad. Pese a todo, la aludida afirmación, más afortunada que sorprendente, tiene una valía aún mayor si se repara en que el gran poeta portugués nunca leyó La muerte y la brújula, de Jorge Luis Borges. No pudo, por lo tanto, conocer a Erik Lönnrot, detective taciturno en un Buenos Aires desdibujado por los adjetivos, disuelto en un mar apátrida de nombres propios.

$\mathrm{El}$ argumento es breve y poderoso. Tres asesinatos, unidos por una simetría cabalística de la que participan la Geografia y el Talmud, empujan al detective a investigar $-\mathrm{y}$, fatalmente, averiguar - el porqué de los crímenes. Su perspicacia le proporciona también el lugar en el que se producirá el cuarto asesinato, que cierra la serie, pero no le advierte de que la víctima será él mismo, Lönnrot.

Como en una antigua leyenda de muertes, esfinges e incestos, el hombre ávido de conocer la verdad es destruido por ésta. La paradoja quiere que Edipo pague con la ceguera los errores cometidos en su vida; este improbable detective paga con su vida los errores debidos a su ceguera.

Con implacable constancia, Lönnrot avanza hasta tocar con los dedos la fatalidad. Son sus sorprendentes instrumentos el examen de la obra erudita de un rabino asesinado, una brújula y un mapa, la traducción de una frase subrayada en el Philologus Hebraeograecus de Leusden. Puede extranar que un detective, personaje que verosímilmente no necesita conocer las 
lenguas clásicas, entienda el latín con suficiencia ${ }^{1}$. Pero el lector de Borges sabe que tamaña habilidad, cuya carencia es comprensible e incluso necesaria en los policías de otros autores, resulta algo natural en un personaje del escritor argentino. Recuérdese que fue éste quien allá por el año 1887 inició en el estudio del latín a un tal Ireneo Funes, dotado de una inconcebible memoria, mediante el préstamo de un volumen de la Naturalis Historia, de Plinio, y el Gradus ad Parnassum, de Quicherat ${ }^{2}$. Fue él también quien rescató de un anonimato quizá temido, tal vez buscado, aquel viejo manuscrito, debido a la pluma de un tribuno romano, en el que deslumbradoramente se retrataba a un Homero que a la inmortalidad de sus poemas añadia la inmortalidad intolerable de su propia existencia física ${ }^{3}$. ¿Hará falta mencionar la multitud de citas y referencias clásicas que, siempre con fortuna, introdujo en sus obras este lector de enciclopedias? El tributo a la cultura grecolatina, sobre todo a su literatura, puede llegar a la exageración: arrastrado por su implacable amor a la paradoja y a la frase lapidaria, Borges perpetra una sentencia según la cual acaso el rústico poema del Cid es el contrapeso exigido por un solo epiteto de las églogas o por una sentencia de Heráclito ${ }^{4}$.

Pero vuelvo al comienzo. He resumido, creo que con pocas palabras y bastante impericia, el triunfo y la caída de Erik Lönnrot. Destaco ahora un momento, el de la llegada del detective a la quinta abandonada de Tristele-Roy, que será su simétrico mausoleo. Al avanzar entre los eucaliptos, ve una Diana en un nicho, a la que en un segundo nicho corresponde otra Diana; ve un balcón que se refleja en otro balcón; ve que un Hermes de dos caras proyectaba una sombra monstruosa. Con el atributo de las dos caras, Borges quiere dar a la estatua el efecto de simetria presente en cada una de las partes que componen la monstruosa quinta. Pero jamás Hermes, el hijo de Zeus y Maya, poseyó tal atributo. Sus representaciones de mayor dignidad incluían el caduceo, las sandalias aladas y el sombrero de ala ancha. Otras más humildes se limitaban a un tronco o pilar con un busto labrado toscamente; se hallaban éstas en las encrucijadas - Hermes protegía a los viajeros- y en las calles de algunas ciudades. En Atenas eran frecuentes ${ }^{5}$.

La explicación no es fácil. ¿Quiso Borges ver la simetría, las dos caras, en la suma de la única cara de la estatua y de la cara proyectada en sombra por ella? No parece desprenderse tal cosa del texto citado. Hay que avanzar un par de páginas en el relato. Lönnrot ha caído en la trampa. Su enemigo,

' La traducción que él hace es un tanto libre, pero eficaz. Buen traductor, sabe sacrificar la literalidad a la desenvoltura.

${ }^{2}$ Véase Funes el memorioso.

'Véase El inmortal.

4 El inmortal, IV.

${ }^{3}$ Los manuales de mitología clásica de Grimal o de Ruiz de Elvira son claros al respecto. 
Red Scharlach, lo tiene a su merced. Antes de darle fin, el criminal realiza esa acción absurda que lo iguala a todos los criminales de la literatura; cuenta a su víctima la razón de la trampa, el porqué de su inevitable muerte ${ }^{6}$. Tres años atrás, Lönnrot encarceló al hermano de Scharlach y lo hirió a él mismo gravemente. Scharlach agonizó nueve días y nueve noches en la delirante quinta: me arrasaba la fiebre, dice, el odioso Jano bifronte que mira los ocasos y las auroras daba horror a mi ensueño y a mi vigilia. Y sin detenerse; Llegué a abominar de mi cuerpo, llegué a sentir que dos ojos, dos manos, dos pulmones, son tan monstruosos como dos caras. Y más adelante: En esas noches yo juré por el dios que ve con dos caras (...) tejer un laberinto en torno del hombre que habia encarcelado a mi hermano.

Creo que Borges pensó siempre en Jano, el dios romano al que se representaba con dos caras, una mirando hacia delante y la otra hacia atrás, el dios capaz de analizar todos los aspectos de cada problema, el dios que en cierta ocasión memorable salvó a Roma. La estatua de dos caras que vio Lönnrot en la quinta tuvo que ser la de Jano. El dios bifronte que llenó las simétricas pesadillas de Scharlach no fue Hermes. ¿Por qué esta confusión de Borges? Apenas hay algo que asemeje a ambos dioses. Una similitud es la gran astucia que Hermes mostró desde su nacimiento, la previsión e inteligencia de Jano. La relación es demasiado tenue.

Cabe otra hipótesis. Fiel a lo que pensaron Marco Flaminio Rufo y los demás inmortales ${ }^{7}$, Borges consideró que el mundo es un sistema de compensaciones precisas; no hay cosa que no esté compensada por otra. En consecuencia, la perfección argumental exigible a la trama de un relato policiaco debe compensarse con algún defecto, por pequeño que éste sea. Es decir, Borges introdujo intencionadamente el error.

Con gusto elegiría esta hipótesis, más interesante que real, porque, como afirma Lönnrot —es decir, Borges-, la realidad puede prescindir de la obligación de ser interesante, pero no las hipótesis. No obstante, el objetivo final de estas páginas es mostrar la realidad como creemos que es, no como nos gustaría que fuera. Y lo más probable es que se trate de una mera distracción de Borges ${ }^{8}$. No por ello debe quedar defraudado el lector. Pues si bien precisamente un romano, Horacio, dejó escrito en su Ars Poetica un implacable indignor quandoque bonus dormitat Homerus, en el verso siguiente

- Un asesino que aborreciera verdaderamente a su víctima no tendría la cortesía de darle explicaciones. Considérese que tales licencias poéticas son un derecho del autor -el lector debe saber de alguna manera la verdad de lo ocurrido-, y obsérvese la innovación: normalmente las explicaciones del criminal dan lugar a que la víctima se salve en último extremo. Lönnrot perece inexorablemente.

' Véase El inmortal, IV.

- Hermes era un dios rico en ardides. Jano presentaba dos caras. ¿Asoció Borges inconscientemente ambas cosas? 
su cólera 'cedió a la comprensión: verum operi longo fas est obrepere somnum .

No haré más por disculpar este lapsus calami. Que yo fuera condescendiente con Borges constituiria demasiada arrogancia. Para disculpar a Homero es necesario ser, al menos, Horacio.

${ }^{9}$ Me indigno cada vez que se duerme el bueno de Homero: / pero en una obra extensa es de ley que aparezca el sueño. 